\title{
Ritual y ceremonia en la catedral de México, \\ $1560-1600$
}

\section{José Gabino Castillo Flores ${ }^{1}$ josegabinocastillo@hotmail.com Ruth Yareth Reyes Acevedo ${ }^{2}$ ruthyarethreyes@hotmail.com}

Ritual and ceremony at cathedral of Mexico, 1560-1600

\section{Resumen}

En el presente trabajo se estudia la importancia que tuvo el ritual catedralicio en México durante los últimos cuarenta años del siglo XVI. En dicho periodo, el cabildo eclesiástico y los arzobispos, pusieron un fuerte empeño por hacer de la catedral de
México la más importante iglesia de la provincia eclesiástica mexicana. En esas tareas, las ceremonias jugaron un importante papel político y religioso, en tanto que a través de ellas el cabildo y la catedral demostrar su preeminencia ante las demás corporaciones de la ciudad.

Palabras clave: ritual, ceremonia, catedral, cabildo, arzobispo.

Abstract

This article examines the importance of Cathedral ritual in Mexico during the last 40 years of the 16th century, a period in which the ecclesiastical Chapter and archbishops strove to make the Mexico City Cathedral the most important church in the ecclesiastical province of Mexico. Among many other initiatives, ceremonies played a significant role -both politically and in religious terms - for it was through them that the Chapter and Cathedral demonstrated their preeminence over other corporations in the city.

Key words: ritual, ceremony, cathedral, chapter, archbishop. versidad y la Educación, México.

Mario de La Cueva, Ciudad Universitaria, Coyoacán, C. P. 04510 Ciudad de México, D.F. El Colegio de Michoacán, México.

Martínez de Navarrete 505, Col. Las Fuentes, C. P. 59699 Zamora Michoacán, México. 
Si bien la Erección de la Iglesia de México, de 1534, estableció en términos generales que la catedral de México quedaba como sufragánea de la de Sevilla, lo cual implicaba que pasaría lo mismo con su ceremonial, en la práctica era imposible que una naciente catedral, recién construida en tierras de conquista y con un cabildo eclesiástico de corto número y escasa experiencia catedralicia pudiera atender el culto como se hacía en la de Sevilla, cuya catedral tenía más de un siglo de existencia. Ésta, a fines del siglo XV, poseía una renta de unos 50 millones de maravedís ${ }^{3}$ (alrededor de 180000 pesos de oro común), mientras que para la década de 1530 los diezmos de la catedral de México promediaban apenas 5000 pesos. ${ }^{4}$ A lo anterior debemos sumar las enormes diferencias en cuanto al capital humano: en 1561, por ejemplo, la catedral de Sevilla era atendida por 81 prebendados, ${ }^{5}$ mientras que en ese mismo año en México sólo había 17 (cuatro dignidades, nueve canónigos y cuatro racioneros). Para este año las rentas de la catedral novohispana eran de 20622 pesos de oro común. ${ }^{6}$

Debido a lo anterior, el cabildo de la catedral de México, al lado de su primer obispo, fray Juan de Zumárraga (1528-1548), construyó el ritual catedralicio a paso lento y adecuándolo a las circunstancias locales. Para empezar, ni siquiera se contaba con un edificio catedralicio en forma; en las instrucciones dadas a su primer procurador, Cristóbal Campaya, en 1536, el cabildo eclesiástico de México puso como su primer tarea solicitar al rey la ayuda para la construcción de una nueva catedral, pues la que había estaba "muy mal edificada y para caer". ${ }^{7}$ Las cosas no mejoraron pronto; todavía en 1554, el entonces cronista y catedrático de la Universidad de México Cervantes de Salazar criticó el estado en que se hallaba la iglesia mayor, por tener un edificio "tan pequeño, humilde y pobremente adornado":

Da lástima que en una ciudad a cuya fama no sé si llega la de alguna otra, y con vecindario tan rico, se haya levantado en el lugar más público un templo tan pequeño, humilde y pobremente adornado; mientras que en España no hay cosa que a Toledo (ciudad por demás nobilísima) ilustre tanto como su rica y hermosa catedral. Sevilla, ciudad opulentísima, es ennoblecida por su excelso y aún mucho más rico templo. Pero

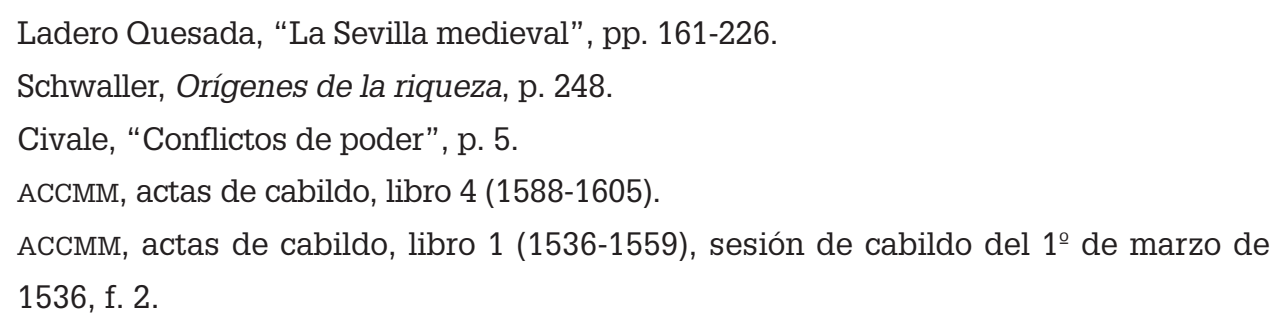


qué mucho, si hasta las iglesias de los pueblos son tan notables y tan superiores a los demás edificios, que siempre es lo más digno de ver que hay en cada lugar. ${ }^{8}$

Otro de los problemas en estos años fue la falta de rentas para construir el coro de la iglesia, espacio indispensable para el cabildo porque en él debía celebrar diariamente el Oficio Divino. ${ }^{9}$ El primero que se construyó, junto con el altar, las oficinas e incluso las puertas de la iglesia, fue obra del mismo Zumárraga quien, se dijo, lo había hecho a su costa. ${ }^{10}$ En 1540 empezaron los trabajos para construirlo, para lo cual se firmó un contrato con el carpintero Juan Franco, vecino de la ciudad, para que manufacturara 24 sillas, más la cátedra obispal. Se acordó que las entregaría en la cuaresma del año siguiente por 260 pesos de oro común. ${ }^{11}$ Sin embargo, una sillería del coro mucho más elaborada, con asientos altos y bajos no fue posible sino hasta la década de 1560.

A pesar de que desde 1530 los canónigos decían que la catedral de México era "tan bien servida como la de Sevilla", pues había "harta copia de clérigos" y las fiestas y domingos se oficiaba con canto de órgano, ${ }^{12}$ uno de los principales problemas radicó en contar con el personal adecuado. En 1540, por ejemplo, Zumárraga se quejó que en Nueva España no había "clérigo que sepa la orden de iglesias catedrales", por lo que pidió a la Corona que se nombrara en las prebendas a personas con experiencia. En marzo de 1541 se le contestó que se tendría en cuenta su petición y se nombraría a quienes ya hubieran servido en iglesias catedrales. ${ }^{13} \mathrm{El}$ ritual era de gran importancia en tanto ayudaba a crear el vínculo entre la catedral y la ciudad en la celebración de la misa conventual o celebraciones anuales como Corpus, Cuaresma, Semana Santa y Navidad.

También durante este periodo se fueron adquiriendo paulatinamente los ornamentos y libros necesarios para las celebraciones, se reguló la actuación de los miembros del cabildo y se luchó porque cumplieran con

Cervantes de Salazar, México en 1554, p. 77.

Sobre la importancia de los coros catedralicios puede verse Navascués Palacio, "Los coros catedralicios". Para el caso novohispano un importante trabajo sobre la materia es el de Díaz Cayeros, "Ornamentación y ceremonia".

ACCMM, actas de cabildo, libro 1 (1536-1559), sesiones de cabildo del 13 de febrero y 13 de abril de 1540, ff. 26-26v y 29.

ACCMM, actas de cabildo, libro 1 (1536-1559), sesión de cabildo del 15 de octubre de 1540, f. 33v.

Real cédula de 20 de octubre de 1530, Carreño, Un desconocido cedulario, pp. 88-89.

Real cédula de 14 de marzo de 1541, Carreño, Un desconocido cedulario, pp. 171-175. 
sus responsabilidades en la catedral. Asimismo, se contrataron los primeros oficiales y ministros que servirían en la iglesia, en el coro y el altar. ${ }^{14}$ Los capellanes, cantores, mozos, etcétera, fueron reclutados de entre la población local, por lo que su circulación fue constante en tanto se buscó encontrar a los más hábiles para el servicio. El esplendor del ritual, sin embargo, dependió de la situación económica de la catedral. En 1540, por ejemplo, cuando el cabildo advirtió una baja en los diezmos, probablemente a causa de las epidemias de matlazáhuatl y viruela que afectaron a la Nueva España entre 1537 y $1539,{ }^{15}$ no quedó más remedio que suspender el canto de órgano a pesar de lo importante que era la música en el ritual catedralicio. ${ }^{16}$

\section{Mejoras y reformas en el ritual catedralicio 1560-1570}

Para la década de 1560, bajo el gobierno de fray Alonso de Montúfar (1554-1572), se avanzó consistentemente en la conformación del ritual. Lo anterior fue posible en gran medida debido a que unos años atrás, en 1546, la catedral de México se había convertido en metropolitana. Para entonces sus estatutos habían servido de base para la erección de las demás catedrales novohispanas. En vista de ello, su cabildo eclesiástico se preocupó porque la catedral sirviera de ejemplo, en materia de ritual y ceremonias, a todas las demás del reino. En ese momento el cabildo estaba conformado por 20 miembros que administraban una renta de $30 \mathrm{mil}$ pesos de oro común. ${ }^{17}$ Ante las variadas medidas que se habían tomado para el orden de las ceremonias, el 24 de agosto de 1563 se discutió si sería conveniente "juntar todos los estatutos que tratan que el coro y culto Para un análisis más detallado de lo que ocurre con la conformación del ritual catedralicio en la catedral de México durante sus primeros años, véase Castillo Flores, "Los primeros tropiezos". Sobre este tema véase García Acosta, Desastres, pp. 96-97. ACCMM, actas de cabildo, libro 1 (1536-1559), sesión de cabildo del 17 de abril de 1540, f. 29v. Como ha indicado Joseph Gelineau, la música es fundamental en el rito cristiano. Se trata de una forma de alabanza que sirve para honrar, pedir y agradecer a Dios. Gelineau, Voices, p. 29. Patricia Díaz Cayeros señala que desde el II Concilio de Tours del año 567 ya se mencionan cantores que debían ser presbíteros en el servicio de la Iglesia. Y para el IV Concilio de Toledo (633) se menciona incluso la presencia de dos coros, uno formado por presbíteros y otro por diáconos. En el siglo VIII surgirá la Schola cantorum integrada por cantores al servicio de las catedrales. Díaz Cayeros, "Ornamentación", pp. 83, 93.

17 Castillo Flores, "La catedral de México", p. 166.
} 
divino sea mejor servido y que se tenga orden en el servir mejor". Se acordó que se reunieran por el maestrescuela y, una vez revisados por todo el cabildo, se llevarán al arzobispo para que los aprobase y "se tuviesen por siempre". ${ }^{18}$ Del resultado de este trabajo y las aportaciones del propio arzobispo, surgieron las reglas del coro establecidas en enero de 1570. En ellas se determinó todo lo concerniente al orden que debía seguirse y las responsabilidades de los capitulares y demás oficiales que participaban en el oficio divino. Las reglas de coro de Montúfar ordenaron que cada quien debía saber lo que le competía hacer. La ordenanza 38 advertía:

Todos los prebendados aprendan a cantar, a lo menos aquellas cosas que a cada uno toca por oficio entonar, a saber: capítulo, oración, lección, prefacio, gloria, credo, oración dominical, ite missa est, benedicamus domino, según la celebridad y el rito de la fiesta; también apréndase con anticipación a entonar en el coro antífona, verso, introito, aleluya, gradual y responsorio. El que no supiere el canto gregoriano para las cosas dichas arriba, esté obligado a aprenderlo dentro de un año, y si pasado éste no lo aprendiere, pierde la décima parte de su prebenda, y prorróguesele otro año bajo la misma obligación; pasado el año pierda la octava parte, y así en adelante guardada la debida proporción auméntese la pena.

Las ordenanzas para el coro contenían las penas correspondientes a las infracciones cometidas por los prebendados, la mayoría ameritaba una reducción salarial. Para su cumplimiento, la vigilancia estaría a cargo del apuntador, éste registraría todas las faltas cometidas durante el servicio del oficio divino, desde la puntualidad hasta la conducta. Se puso énfasis en los comportamientos que había que evitar, con la finalidad de que el oficio divino se celebrara en forma correcta, pues en ello iba de por medio la dignidad capitular; platicar, reír, hacer ruido, ser negligente en el canto o la lectura y ausentarse sin licencia del presidente, entre otras, se consideraban algunas de las conductas más reprobadas. ${ }^{19}$

En lo que atañe a la música, desde los inicios del arzobispado de Alonso de Montúfar se acordó que fuera parte de las ceremonias catedralicias para "mayor conversión de los infieles". ${ }^{20}$ Para que la música fuera lo bastante preciada era necesario contar con músicos capacitados que pudieran aumentar el boato del culto; desde 1539 la catedral

\footnotetext{
18 ACCMM, libro 2 (1559-1576), actas de cabildo, sesión del 24 de agosto de 1563, f. 108.

19 "Orden que debe observarse en el coro".

20 ACCMM, actas de cabildo, libro 1 (1536-1559), sesión del 16 de octubre de 1554, f. 105v.
} 
ya contaba con un sochantre, cantores, mozos de coro y un maestro de capilla que tenían la responsabilidad de solemnizar las principales celebraciones. Asimismo, dado que el órgano es el instrumento eclesiástico por excelencia, se contó con organistas desde fechas muy tempranas. Los primeros de los que se tiene noticia fueron el clérigo Juan de Alcalá, quien servía en catedral desde $1531,{ }^{21}$ y Antonio Ramos, quien ejercía el oficio en 1539, con el encargo de tocar el órgano "los domingos y fiestas de guardar y días de primera y segunda dignidad".22 Para 1599 el cabildo se daba el gusto de decir que contaba con un órgano grande que era de los "buenos que hay en este reino", aunque estaba maltratado y "estragado". En ese año se acordó mandar a hacer un nuevo órgano pequeño para solemnizar las fiestas menos importantes. ${ }^{23}$ El cabildo buscó siempre contar con buenos organistas; desde enero de 1567 hasta su muerte, ca 1594, contó con Manuel Rodríguez de Mesa, quien había servido antes en la catedral de Puebla. ${ }^{24}$ Tras su muerte, el cabildo recibió en el puesto a su hijo Alonso:

atento a lo bien que sirvió Manuel Rodríguez de Mesa [...] y considerando la mucha estrechesa ( $(\mathrm{ic}$ ) y pobreza que tuvo en treinta y más años que sirvió [...] que habiéndose de dar este oficio a persona que a él convenga a esta santa iglesia si se hubiese de buscar en todo este reino no se hallaría ninguna más a propósito ni de más suficiencia en el órgano que Alonso Rodríguez de Mesa hijo del dicho difunto, ni que mejor pueda acudir a servir el dicho oficio por ser de tan buena mano que la del dicho su padre no se echa menos. ${ }^{25}$

El interés por un mayor lucimiento de las ceremonias se fortaleció a fines de la década de 1560, cuando el cabildo eclesiástico empezó a reforzar su espíritu de cuerpo. ${ }^{26}$ Para 1570 el rostro del cabildo empezaba a

\footnotetext{
21

22

24

25

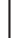
AGI, Audiencia de México, 1088, L.1BIS, F.93V-94R.

ACCMM, actas de cabildo, libro 1 (1536-1559), sesión de cabildo del 15 de noviembre de 1539 , f. 22.

ACCMM, actas de cabildo, libro 4 (1588-1605), sesión de cabildo del 16 de julio de 1599 , f. 226.

ACCMM, actas de cabildo, libro 2 (1559-1576), sesión de cabildo del 28 de enero de 1567. ACCMM, actas de cabildo, libro 4 (1588-1605), sesión de cabildo del 13 de junio de 1595 , f. 123.

El concepto de "espíritu de cuerpo" lo hemos tomado de Óscar Mazín, quien advierte que el cabildo de Valladolid de Michoacán, durante el periodo de 1650 a 1666, logra afianzarse gracias al reforzamiento de una conciencia capitular que restableció la cole-
} 
modificarse y había en él una fuerte presencia de prebendados novohispanos muy vinculados con las élites locales. Estos personajes mejoraron el aparato administrativo de la catedral, que para 1575 recaudaba ya 40 mil pesos de oro común como renta decimal lo que, a su vez, posibilitó que por primera vez en esta década casi se cubrieran las plazas completas del cabildo (en 1578 estaban ocupadas 26 de las 27 prebendas disponibles).

Fue así que durante la década de 1560 el cabildo eclesiástico de México buscó distinguirse de las demás corporaciones novohispanas. Uno de los medios utilizados para ello fueron las ceremonias públicas. Un ejemplo de éstas lo tenemos en los entierros. En 1557 el cabildo acordó que para evitar el continuo llamado que se le hacía a entierros y honras fúnebres, lo cual desacreditaba la autoridad y dignidad de la corporación, se debía cobrar una suma de dinero mayor que la que hasta entonces se pedía. Con base en ello se estableció que no se fuera a ningún entierro a menos de que se pagaran 100 pesos de minas si se realizaba fuera de la catedral o 60 si era dentro de ésta; por honras fúnebres fuera del recinto se cobrarían 30 pesos de minas y dentro de éste 20 . Aunque esto fue autorizado por el arzobispo, no todo el cabildo estuvo de acuerdo, entre ellos los prebendados Ávila y Peñas, quienes expresaron que aumentar el estipendio de los entierros no era conveniente debido a que serían vistos como codiciosos. Sin embargo, la mayoría estuvo de acuerdo, alegando que con ello no se hacía más que seguir la tradición de las catedrales castellanas en la cuales el cabildo no asistía sino a entierros de personas distinguidas:

por cuanto en los reinos de Castilla los cabildos de las iglesias catedrales no salen a enterrar a los difuntos si no son personas calificadas, que lo mismo se cumpla y guarde por los capitulares de esta santa iglesia, atento a la calidad y preeminencia de esta dicha santa iglesia sobre las demás de esta Nueva España. ${ }^{27}$

Bajo el gobierno del arzobispo Pedro Moya de Contreras (1572-1591) incluso se ordenó que el cabildo asistiera a los entierros a los que fuera llamado "sin hacer excepción de personas", siempre que por el entierro dentro de la iglesia pagaran 150 pesos de tepuzque y por los que se realizaran en otra iglesia 200. Según se acordó, el estipendio no incluía la presencia de la capilla de música. Con esta decisión, el gobierno catedralicio

gialidad entre los miembros de aquella corporación, lo que permitió la consolidación del proyecto catedralicio. Mazín Gómez, El Cabildo catedral, pp. 145-174.

27 ACCMM, actas de cabildo, libro 2 (1559-1576), sesión de cabildo del 9 de mayo de 1559, f. 4. 
buscó cuidar su imagen pública y que no se les calificara como un cuerpo excluyente; sin embargo, el simple aumento del precio recalcaba la decisión de asistir sólo a los sepelios de personajes distinguidos.

En 1576 el cabildo estipuló una nueva prohibición para garantizar la preeminencia de la catedral ordenando que "ningún negro esclavo ni libre de cualquier calidad que sea se entierre dentro de la iglesia". ${ }^{28}$ Esto sirvió como complemento de una orden anterior sobre que la manga de cruz que se había mandado hacer para los entierros no fuera usada por los sacerdotes de la catedral para enterrar mestizos ni mulatos.

Años más tarde, en 1583, el alza en las tarifas y el aumento de prerrogativas por parte del cabildo desató las críticas del Ayuntamiento de la ciudad. Por medio del regidor Juan Vázquez de Salazar, se apeló ante la Real Audiencia por lo que consideraron "excesivos derechos en enterramientos y honras" para los vecinos. El cabildo, sin embargo, no se quedó con los brazos cruzados; en sesión de diciembre del mismo año acordó responder por medio de su solicitador para que el pleito "con mucho calor se siga". ${ }^{29}$ El Ayuntamiento nada pudo hacer: en 1592 se seguía quejando, esta vez ante el gobernador del arzobispado, por el aumento de los estipendios para los entierros en la catedral y las parroquias. Pero los intentos de distinción, como sucedía en la Península, no eran mal vistos por los vecinos, a lo menos por aquellos que buscaban el mismo reconocimiento. En 1601, por ejemplo, el cabildo había prohibido sepultar a cualquier persona en el Sagrario a menos que se diera una licencia especial, la cual no se tuvo inconveniente en otorgar al mercader Alonso Díaz de la Barrera, quien la solicitó para enterrar ahí a su sobrina a cambio de 200 pesos de limosna.

La asistencia del cabildo a las fiestas también fue restringida. Se acordó que el cabildo no saliera en procesión a ninguna parte de las que solía ir si no fuere a la de San Hipólito por ser ya "devoción del pueblo introducida", y que a las fiestas que los cofrades pidieran celebrar al cabildo fuera sólo un canónigo, un racionero y un capellán para decir la misa mayor y no más. De igual manera, el cabildo intentó tener un mayor control sobre la capilla de música. En 1557 se prohibió que los cantores fueran a entierros o cualquier otra parte sin licencia del cuerpo capitular. Esto fue confirmado en 1571 con mayor severidad, pues el castigo económico que se impuso por esta falta se hizo extensivo para el maestro de capilla.

28 ACCMM, actas de cabildo, libro 3 (1576-1588), sesión de cabildo del 27 de noviembre de 1576 , f. $18 \mathrm{v}$.

29 ACCMM, actas de cabildo, libro 3 (1576-1588), sesión de cabildo del 6 del diciembre de 1583, fs. $185 \mathrm{v}-186$. 
Casi una década después, se planteó la impropiedad de que los cantores que tuvieran alguna prebenda asistieran a las celebraciones que acudía la capilla, por ello se ordenó que aunque dicha capilla fuera

a cantar a otra parte fuera de la iglesia, no se entienda que se da la dicha licencia a los prebendados cantores de esta santa iglesia ni a los capellanes de ella sino que antes cumplan lo susodicho so pena de dos pesos por cada vez que lo contrario hicieren lo que está proveído y mandado que no vayan a cantar fuera de esta dicha santa iglesia y renovaban y renovaron lo que de suso se refiere que está proveído en este caso. ${ }^{30}$

Estas restricciones a los músicos se fortalecieron, a la par que se buscó hacer de la música un signo distintivo de la catedral en las procesiones. Para ello los capitulares empezaron a convocar a todos los cantores y ministriles (músicos que tañían instrumentos de cuerdas o viento) para que los acompañaran cuando salieran en forma de cuerpo fuera de la iglesia. ${ }^{31}$ Esto explica también el pleito surgido con el arzobispo en 1567 cuando pretendió que, en las procesiones, el cabildo compartiera su lugar con los provinciales de las órdenes religiosas. Montúfar señaló que al frente irían el deán y el arcediano, seguidos de los provinciales, posteriormente las otras dignidades acompañadas de los priores de las dichas órdenes, y luego los canónigos y demás religiosos. El cabildo de inmediato rechazó aquella orden e inició su defensa en los tribunales. En su alegato, el arzobispo se valió de su provisor, Esteban del Portillo, quien señaló que en las procesiones generales los prelados de las órdenes mendicantes habían ido al lado de los capitulares hasta fecha reciente en que éstos se negaron a aceptar ese orden..$^{32}$

Más allá de este conflicto, los prebendados buscaron dar realce a celebraciones como la de Corpus Christi, para la cual se buscó contar con todos los ornamentos y música necesarios para su mayor esplendor. Fue en este periodo cuando se instituyó en la catedral una fiesta solemne en honor del Santísimo Sacramento, que se realizaría dentro de la catedral el primer domingo de cada mes:

y para mayor conversión de los infieles de esta tierra, acordaron [...] teniendo atención a lo que se usa en España, de ordenar una fiesta

\footnotetext{
30 ACCMM, actas de cabildo, libro 3 (1576-1588), sesión de cabildo del 21 de junio de 1580, f. 97.

31 Aviña Levy, Descripción, p. 282.

32 Lundberg, Unificación, pp. 210-211.
} 
solemne del Santísimo Sacramento [...] cada domingo primero de cada mes por dentro de la iglesia sacando el Santísimo Sacramento y volviéndolo a su lugar ordinario con toda la música y solemnidad que conviene para tan alta fiesta y que se predique todas las fiestas. ${ }^{33}$

Estas fiestas, como se expresa en la cita anterior, debían estar acompañadas de música sacra de gran calidad. De ahí la importancia de mantener una adecuada capilla de música, conformada de excelentes cantores y ministriles. Desde 1562 se acordó que todos los capellanes fueran con el maestro de capilla, Lázaro del Álamo, para que aprendieran a cantar y sirvieran en dichas celebraciones. ${ }^{34}$ Algunos prebendados de la catedral servían entonces como cantores de la capilla y con ello aumentaban sus ingresos. Para mediados de la década, el racionero Álamo sumaba 150 pesos de minas a su prebenda por el cargo de maestro de capilla; el canónigo Oliva, 100; y el canónigo Pedro Garcés, 50. El buen ejercicio en este oficio fue precisamente el que les abrió las puertas a los hermanos Alonso de Écija y Serván Ribero, únicos tiples con los que contaba entonces la capilla, para obtener sus prebendas en la catedral, el primero como racionero en 1571 y el segundo como medio racionero en 1577 (cuadro 1). Desde 1563 quedaron estipuladas las fechas en que debían estar presentes, sin excepción, todos los cantores y ministriles de la dicha capilla.

Primeramente todos los días de fiesta de guardar a primeras vísperas y procesión y misas.

Todos los domingos del Santísimo Sacramento, procesión y misa.

Todos los domingos de adviento y de septuagésima y cuadragésima, procesión y misas.

Todos los días que hay seña a vísperas.

Los tres días de Tinieblas y jueves y viernes y sábado de la Semana Santa a misa. ${ }^{35}$

Asimismo, se determinó que el organista debía asistir para acompañar las ceremonias:

33

34

35

ACCMM, actas de cabildo, libro 2 (1559-1576), sesión de cabildo del 16 de octubre de 1554, f. 105v.

ACCMM, actas de cabildo, libro 2 (1559-1576), sesión de cabildo del 6 de febrero de 1562 , f. $68 \mathrm{v}$. ACCMM, actas de cabildo, libro 2 (1559-1576), sesión de cabildo del 12 de enero de 1563, ff. $94 \mathrm{v}-95 \mathrm{v}$. 
todos los días de primera y segunda dignidad, primeras y segundas vísperas y procesión y misa y en las octavas solemnes los tres días principales, misa, vísperas y el día de la octava. Todos los domingos del año primeras y segundas vísperas y procesión y misa y a todos los domingos de adviento y septuagésima y cuadragésima si no fuere cuando hubiere procesión del Sacramento que ha de tañer a ella todos los sábados que se rezare de Nuestra Señora a misa. ${ }^{36}$

Por otro lado, haciendo eco de las críticas del arzobispo, los capitulares buscaron mejorar la disciplina interna del cabildo. Se acordó que en el coro hubiera el recato necesario y se evitara que los prebendados anduvieran saliendo de él, o que no estuvieran en sus sillas al momento del rezo de las horas. Se solicitó también que en el cuerpo de la iglesia ningún cura de la catedral o capellán dijera misa mientras se rezaba el Oficio Divino o se dijera la misa mayor. ${ }^{37}$ Además de ello, se acordó poner una ampolleta (un reloj de arena) en el coro que rigiera el inicio de las horas, pues era común que los prebendados llegaran tarde debido a lo dispar de los relojes de la ciudad. ${ }^{38}$ El intento por mejorar el culto se reforzó señalando la necesidad de que nunca se dejara de decir la misa mayor y ésta se dijera con toda la solemnidad posible. Para ello se decidió, además, aumentar a doce el número de mozos de coro, aunque en la erección de la iglesia se hubiera señalado seis. ${ }^{39}$ En las misas de fiestas importantes, el cabildo de México incluso podía recurrir al colegio de San Juan de Letrán para que algunos de sus colegiales ayudaran en las celebraciones. Este interés por normar todo lo referente al culto con la finalidad de garantizar su esplendor y decoro existió también en la catedral de Puebla durante el mismo periodo. El cabildo de dicha catedral, a partir de 1570, inició importantes reformas en materia de ritual, sobre todo en lo referente al cumplimiento exacto del oficio divino y a la disciplina de los capitulares en el coro. ${ }^{40}$

Pero el culto divino no estaba completo sin los ornamentos necesarios. Por tal razón, el cabildo eclesiástico de México continuó com-

36

37

38

39 0

ACCMM, actas de cabildo, libro 2, (1559-1576), sesión de cabildo del 12 de enero de 1563, ff. $94 \mathrm{v}-95 \mathrm{v}$. ACCMM, actas de cabildo, libro 1 (1536-1559), sesión de cabildo del 11 de noviembre de 1557, f. 151. ACCMM, actas de cabildo, libro 2 (1559-1576), sesión de cabildo del 27 de octubre de 1559, ff. $14 \mathrm{v}-15 \mathrm{v}$. ACCMM, actas de cabildo, libro 2 (1559-1576), sesión de cabildo del 19 de agosto de 1559, ff. $7 \mathrm{v}-8$.

Sobre el tema véase Peña Espinosa, "El oficio divino". 
prando, ya a nivel local o bien de la península, los ornamentos, libros y paramentos necesarios para las celebraciones litúrgicas. Los propios prebendados remarcaron desde temprana fecha la importancia de estos objetos en tanto una de las mayores críticas que se hacían a la catedral, además de su pobre fábrica, era su carencia de ornamentos. Por tal razón, en 1561, se enviaron a Castilla 12 mil pesos para su compra. En aquella ocasión el cabildo advirtió también la necesidad de reparar la catedral, pues debía ser "la principal" del reino y con ello poner fin a las "murmuraciones del pueblo" 41 por el estado en que se encontraba. La situación no era muy diferente en el resto de las catedrales; todavía en 1569 el cabildo eclesiástico de Guadalajara se refirió así a su catedral: "la iglesia catedral desta ciudad es de adobes y cubierta de paja, y así son las iglesias de todo el reino". ${ }^{42}$

Es difícil dar crédito que la principal catedral de la Nueva España se encontrara en un estado tan deteriorado y que aún no se pudiera dar comienzo a la nueva obra que supuestamente se construiría. El arzobispo Montúfar, sin embargo, sabía que lo escaso de las rentas mantenían estancado el proyecto de construcción. Su idea de que se construyera una catedral similar a la de Sevilla pronto demostró su inviabilidad, por lo que se conformó con planear una iglesia de menores dimensiones, comparable acaso con la de Segovia; este proyecto, más viable, podría realizarse en unos 20 o 30 años. ${ }^{43}$ A pesar de que Montúfar bendijo el terreno donde estaría la nueva catedral y se echaron los cimientos, la obra quedó pendiente para años más tarde.

Hoy martes primero de febrero de 1564 años, entonces se bendijo la iglesia mayor, el arzobispo en persona hizo la bendición junto con los grandes sacerdotes de San Francisco, San Agustín, Santo Domingo y los clérigos. Sólo las dignidades eclesiásticas acompañaron al arzobispo e hicieron la bendición, llevaban puestas las dalmáticas y se tocaron las campanas. Y estuvieron todos los diferentes señores, principales, el virrey, los oidores y nuestros gobernantes de México los alcaldes. Y se dijo misa ahí donde se hizo la bendición [...]. Y una vez que hizo la

41

42

43 Lundberg, Unificación, p. 217. $1561,59 \mathrm{v}$. nez, "Enseñanza".

"Informe al rey por el cabildo eclesiástico de Guadalajara acerca de aquel reino", disponible en http://www.memoriapoliticademexico.org/Textos/1Independencia/1569IGD. html. Sobre la conformación del ritual en la Nueva Galicia puede verse Becerra Jimé- 
bendición luego ya se echó cal en donde ya estaban hechas las zanjas, a todas se les echó cal, ahí se requirieron las grandes piedras que fueron arrastradas. ${ }^{44}$

\section{Ritual y ceremonia en el último tercio de siglo}

Los prelados buscaron dar realce al ritual, por lo cual fue común que normaran en esta materia. Se vio ya el ejemplo de fray Alonso de Montúfar, quien publicó las reglas del coro de 1570. Por su parte, Pedro Moya de Contreras (1572-1591), además de insistir en la correcta ejecución del ritual por parte de su cabildo y en darle el realce necesario, convocó al Tercer Concilio Provincial Mexicano (1585), cuyos documentos, si bien no se imprimieron sino hasta 1624, dejaron constancia de las preocupaciones del prelado en esta materia. En sus estatutos se aprecia el interés de Moya de que el ritual catedralicio se llevara a cabo de manera correcta, en especial porque se trataba de la catedral de México que, se dijo, era "metropolitana y regla de donde es justo tomen dechado las demás iglesias sufragáneas, así en las ceremonias que se deben guardar en el coro como en todas las demás cosas anejas y pertenecientes". ${ }^{45}$ La frase anterior denota no sólo el hecho de que la catedral era la principal iglesia del reino, sino la necesidad de homologar el culto, tal como se había mandado en el concilio de Trento. Esta religiosidad postridentina llamaba a exaltar las ceremonias públicas (aquello tan criticado por Lutero) a fin de propiciar la fe de los asistentes.

El cabildo buscó realzar determinadas fiestas ${ }^{46}$ que tenía como principales, entre ellas Navidad, Reyes, la Ascensión, Pentecostés, la Semana Santa, Corpus Christi, San Pedro y San Pablo, la Asunción, Santa Ana, San Miguel y Todos Santos, días cuyas vísperas se solemnizaban

44

45

46 guientes días: Fiestas de enero: La circuncisión de Nuestro Señor Jesucristo, La epifanía del Señor y Santos Sebastián y Fabián. Fiestas de febrero: La purificación de María Santísima y San Matías apóstol. Fiestas de marzo: Santo Tomás de Aquino, El castísimo patriarca Señor San José, esposo de la Santísima Virgen y la Encarnación del Divino Verbo. Fiestas de abril: San Marcos, evangelista. Fiestas de mayo: Santos Felipe y Santiago, apóstoles y la Invención de la Santa Cruz. Fiestas de junio: San Bernabé, apóstol: la natividad de San Juan Bautista y los Santos Apóstoles Pedro y Pablo. Fiestas de julio: La Visitación de María Santísima, Santa María Magdalena, 
con música de órgano y cuyas misas se celebraban con asistencia de la capilla de música y portando capas los prebendados. ${ }^{47}$ Se daban incluso unos días de licencia para faltar al cabildo al maestro de capilla, a fin de que compusiera las letras para tales celebraciones. En 1591, por ejemplo, se acordó que contara con 40 días previos a navidad y Corpus, cuatro antes de San Miguel y tres anteriores a las fiestas de San Pedro y la Asunción. ${ }^{48}$

Para que en las celebraciones se guardaran el orden y la solemnidad debidos, el cabildo ordenó que no faltaran los prebendados, por lo que se prohibió que esos días se otorgara recle $e^{49}$ y que el patitur ${ }^{50}$ se diera sólo ante evidente enfermedad. Lo mismo se aplicó a los demás servidores de la catedral, pues se denunciaba lo mal que se servía el culto por las licencias que solían darse al sochantre, los capellanes y curas. ${ }^{51}$ Con más razón aún, dichos señalamientos se dirigieron a la capilla de música, la cual hasta 1560 fue común que saliera a solemnizar otras ceremonias, o incluso a amenizar fiestas profanas, a fin de hacerse de

Santiago, apóstol, y Señora Santa Ana. Fiestas de agosto: Santo Domingo, la Transfiguración del Señor, San Lorenzo, mártir; San Hipólito, la Asunción de María Santísima, San Bartolomé, apóstol, y San Agustín. Fiestas de septiembre: la natividad de Nuestra Señora, San Mateo, apóstol y evangelista, y San Miguel Arcángel. Fiestas de octubre: San Francisco, San Lucas, evangelista, y los Santos Apóstoles Simón y Judas Tadeo. Fiestas de noviembre: Todos los Santos, Santa Catalina, virgen y mártir, y San Andrés, apóstol. Fiestas de diciembre: La Inmaculada Concepción de María Santísima, la Expectación del parto de Nuestra Señora, Santo Tomás, apóstol; la Natividad de Nuestro Señor Jesucristo; San Esteban, protomártir, y San Juan, apóstol y evangelista. Como complemento de los días anteriores se ordenó guardar algunos días móviles: el domingo de Resurrección "y los dos días siguientes"; la Ascensión del Señor y el domingo de Pentecostés con sus "dos días siguientes". Tercer concilio provincial mexicano, libro II, tít. III, cap. I, "Días de fiesta que se han de guardar de precepto". Martínez, Concilios Provinciales Mexicanos. ACCMM, actas de cabildo, libro 3 (1576-1588), sesión de cabildo del 24 de julio de 1587, f. 248. ACCMM, actas de cabildo, libro 4 (1588-1605), sesión de cabildo del 12 de noviembre de 1591, f. $62 \mathrm{v}$. Los capitulares tenían derecho a un lapso de dos meses al año que tomaban como descanso, éste se podía tomar junto o bien en días separados. Permisos para faltar ante una imposibilidad notoria.

51 ACCMM, actas de cabildo, libro 3 (1576-1588), sesión de cabildo del 2 de octubre de 1579, f. $83 \mathrm{v}$. 
ingresos extras. ${ }^{52}$ A partir de 1571, sin embargo, se empezó a exigir de manera tajante que dicha capilla no saliera de la catedral sino con licencia de todo el cabildo. ${ }^{53}$ Lo cierto es que para entonces la capilla no tenía la importancia que cobraría bajo el arzobispo Moya de Contreras. De hecho, para 1579 aún seguía sin tener la calidad necesaria y sus músicos parecían atender poco a las órdenes del cabildo, razón por la cual se decidió despedirlos a todos, "atento a que no había de toda la copia más de dos". ${ }^{54}$

Fue a partir de 1580 cuando la capilla de música empezó a tener la jerarquía deseada, no sin algunas resistencias del cabildo debido a los costos de mantenerla, especialmente tras la epidemia de 1576 que había generado algunas bajas en los diezmos. ${ }^{55}$ Lo primero en lo que se insistió

52

(1)

En forma de anexo al final de este artículo están las listas de los personajes que fueron contratados entre 1570-1600 para dar lucimiento a las ceremonias. Se trata de los mozos, cantores, ministriles, maestros de capilla y organistas que hubo en este periodo en la catedral.

"Se proveyó por la mayor parte de los dichos señores deán y cabildo que el maestro de capilla de esta santa iglesia [no vaya a] ninguna parte fuera de ella sin expresa licencia de los dichos señores deán y cabildo, so pena que si de este mando excediere él y todos los cantores que allá fueren serán multados en cuatro pesos cada uno". ACCMM, actas de cabildo, libro 2 (1559-1576), sesión de cabildo de 22 de junio de 1571, ff.267v-268. El 2 de mayo de 1562 se dio una de las primeras prohibiciones señalándose que ni el maestro de capilla ni los cantores fueran a ningún entierro o cabo de año sin licencia del cabildo, so pena de seis pesos para el primero y tres para los cantores desobedientes. Asistir a este tipo de ceremonias era frecuente en tanto representaban ingresos adicionales para los músicos. ACCMM, actas de cabildo, libro 2 (1559-1576), sesión de 2 de mayo de 1562, f. 52.

ACCMM, actas de cabildo, libro 3 (1576-1588), sesión de cabildo del 7 de abril de 1579, fs. $72 \mathrm{v}-73$.

En 1582, por ejemplo, el cabildo decidió bajar los sueldos que ganaban el maestro de capilla, los cantores y ministriles. El maestro ganaría sólo 300 pesos de los 600 que tenía, mientras que los cantores tuvieron, en promedio, una rebaja de 50 pesos a sus salarios de 200. Los ministriles perdieron alrededor de una tercera parte de sus ingresos. Entonces servía como maestro el racionero Hernando Franco; como cantores Pero Martín, Juan Hernández, Bartolomé Franco, Luis de Toro, padre Pero López, Marcos Tello, Agustín Díaz, Antonio Ortiz y el canónigo Écija; y como ministriles Bernardino Rodríguez, Álvaro de Covarrubias, Francisco de Covarrubias, Miguel de los Reyes y Julián Hurtado de Mendoza. ACCMM, actas de cabildo, libro 3 (1576-1588), sesión de cabildo del 6 de julio de 1582, ff. 651-653. La mayoría de ellos renunció luego de aquellas rebajas, mas el arzobispo solicitó al cabildo que mantuviera la ca-

Letras Históricas / Número 14 / Primavera-verano 2016 / México / pp. 17-49 / ISSN: 2007-1140 
fue en encontrar organistas, ministriles y cantores capaces. De acuerdo con las actas del cabildo eclesiástico, el primer ministril contratado fue Bartolomé de Luna, el 8 de octubre de 1574, a quien se le pagarían 200 pesos de oro común al año a fin de que sirviera también como cantor y diera "lección a los indios chirimías tres veces en la semana". ${ }^{56}$ Poco después, en 1581, se estaba tratando de traer de Pátzcuaro a un bajón. ${ }^{57}$ Hubo ocasiones en que también los buenos cantores de la catedral, como Juan Hernández, recibieron ofrecimientos de otras catedrales, en este caso la de Puebla, para que sirvieran en ellas con mejor salario que el que tenían en México y la no menos atractiva propuesta de una prebenda. Pero el interés de Moya por mantener en México buenos músicos le hizo prometer a Hernández abogar por él para obtener una prebenda en dicha catedral. Moya cumplió su promesa luego de marcharse a la Península, donde consiguió que el cantor obtuviera su ración a cambio de servir como maestro de capilla, ${ }^{58}$ en sustitución del anterior maestro, Hernando Franco, a quien igualmente Moya le había conseguido su prebenda. ${ }^{59}$

Pero el más claro interés puesto por la catedral y el arzobispo para tener una capilla de calidad se dio en 1590, cuando el exprocurador de la catedral, Rodrigo Muñoz, trajo consigo seis ministriles de Castilla "para el ornato y servicio del culto divino en esta dicha santa iglesia",

pilla por la importancia que revestía para el culto, razón por la cual el cabildo decidió conservarla. Lo que jugó a favor del arzobispo y la capilla en esta ocasión fue que el rey donó sus dos novenos para la fábrica por seis años, que correrían de enero de 1583 a 1589. ACCMM, actas de cabildo, libro 3 (1576-1588), sesión de cabildo de 22 de agosto de 1582, ff. 655-656. Dichos dos novenos pertenecían al rey por derecho de patronato, mas durante todo el siglo XVI fue común que los donara a la fábrica catedralicia. ACCMM, actas de cabildo, libro 2 (1559-1576), sesión de cabildo de 8 de octubre de 1574, f. 296. ACCMM, actas de cabildo, libro 3 (1576-1588), sesión de cabildo de 21 de abril de 1581, ff. $115 \mathrm{v}-116$. ACCMM, actas de cabildo, libro 4 (1588-1605), sesión de cabildo de 28 de julio de 1589 , ff. 20-21. Franco había fungido como maestro de capilla desde el 20 de mayo de 1575, cuando sustituyó al anterior maestro Juan de Victoria, con 600 pesos de oro común de salario al año. Hernando Franco contó con el apoyo del arzobispo Moya de Contreras, quien lo recomendó ante el Consejo de Indias en 1581. En marzo de ese año el Consejo propuso a Franco para la ración en México. CCMM, actas de cabildo, libro 2 (1559-1576), sesión de cabildo del 20 de mayo de 1575, f. 308v. 


\section{Cuadro 1}

Prebendas otorgadas en la catedral de México a clérigos que poseían conocimientos de música (1570-1600)*

\begin{tabular}{|c|c|c|c|c|c|}
\hline Nombre & Oficio & $\begin{array}{l}\text { Año de } \\
\text { ingreso } \\
\text { como } \\
\text { músico }\end{array}$ & $\begin{array}{c}\text { Año de } \\
\text { ingreso } \\
\text { a la } \\
\text { prebenda }\end{array}$ & $\begin{array}{c}\text { Prebenda } \\
\text { otorgada }\end{array}$ & Origen \\
\hline $\begin{array}{l}\text { Alonso de } \\
\text { Écija }\end{array}$ & Cantor & 1564 & $\begin{array}{l}1571 \\
1577\end{array}$ & $\begin{array}{l}\text { Ración } \\
\text { Canonjía }\end{array}$ & Novohispano \\
\hline $\begin{array}{l}\text { Lorenzo de } \\
\text { Sola }\end{array}$ & Cantor & 1575 & 1577 & $\begin{array}{l}\text { Media } \\
\text { ración }\end{array}$ & Español \\
\hline $\begin{array}{l}\text { Juan } \\
\text { Hernández }\end{array}$ & $\begin{array}{l}\text { Cantor y } \\
\text { maestro de } \\
\text { capilla }\end{array}$ & 1568 & $\begin{array}{l}1577 \\
1589\end{array}$ & $\begin{array}{l}\text { Media } \\
\text { ración } \\
\text { Ración }\end{array}$ & Español \\
\hline $\begin{array}{l}\text { Serván } \\
\text { Ribero }\end{array}$ & Cantor & 1559 & 1577 & $\begin{array}{l}\text { Media } \\
\text { ración }\end{array}$ & Novohispano \\
\hline $\begin{array}{l}\text { Hernando } \\
\text { Franco }\end{array}$ & $\begin{array}{l}\text { Maestro de } \\
\text { Capilla }\end{array}$ & 1575 & 1581 & Ración & Español \\
\hline $\begin{array}{l}\text { Bartolomé } \\
\text { Franco }\end{array}$ & Cantor & ca 1564 & 1589 & Ración & Novohispano \\
\hline $\begin{array}{l}\text { Antonio Ortiz } \\
\text { de Zúñiga }\end{array}$ & $\begin{array}{l}\text { Cantor y } \\
\text { maestro de los } \\
\text { mozos de coro }\end{array}$ & 1577 & 1590 & $\begin{array}{l}\text { Media } \\
\text { ración }\end{array}$ & Novohispano \\
\hline $\begin{array}{l}\text { Antonio de } \\
\text { Yllana }\end{array}$ & $\begin{array}{l}\text { Cantor y } \\
\text { maestro de los } \\
\text { mozos de coro }\end{array}$ & 1590 & 1590 & $\begin{array}{l}\text { Media } \\
\text { ración }\end{array}$ & Español \\
\hline Luis de Toro & Cantor & $?$ & 1592 & Ración & Novohispano \\
\hline $\begin{array}{l}\text { Sebastián } \\
\text { Pérez de } \\
\text { Ribera }\end{array}$ & Cantor & $?$ & 1597 & $\begin{array}{l}\text { Media } \\
\text { ración }\end{array}$ & Novohispano \\
\hline
\end{tabular}

* Durante el periodo de Moya, varios personajes que habían servido en la catedral desde niños lograron obtener alguna prebenda, si bien de las menores (raciones y medias raciones). Ello abrió las puertas a los naturales de la Nueva España que tuvieran experiencia y pericia en la celebración del culto.

Fuente: ACCMM.

los cuales venían obligados a "servir por cierto tiempo sin que en él pudieren servir en otra iglesia en esta Nueva España". Venían además con dichos ministriles dos niños capones (castrados) que servirían como tiples en dicha catedral; se trataba de Tomás López y Pedro de Salcedo. 
Entre los ministriles llegó Antonio de Yllana, quien venía presentado como racionero, "atento a su mucha habilidad en la música, en especial para enseñar a los mozos de coro de esta dicha santa iglesia". ${ }^{60}$

Las últimas dos décadas del siglo se caracterizaron por buscar que la capilla fuera exclusiva de la catedral. ${ }^{61}$ En 1595 se advirtió a todos los cantores y ministriles que estaban sujetos al maestro de capilla, quien llevaría un registro de todas la faltas que cometieran y de cada vez que se ausentaran cuando se celebrara alguna de las fiestas, ya fuera solemne o no, en la catedral. ${ }^{62}$ Se puso especial cuidado en la fiesta del Santísimo Sacramento, para su celebración incluso los oficiales menores de la catedral debían acudir adecuadamente vestidos. Un ejemplo de ello lo tenemos en 1575, cuando el cabildo mandó hacer unas opas para los mozos del coro de "escarlatín de Castilla o grana de la tierra" para dicha fiesta. ${ }^{63}$ Durante la celebración, el cabildo buscaba tener un lugar prominente, aunque no dejaba de haber tropiezos, pues a veces sus intenciones se veían obstaculizadas por algunas personas que usurpaban sus lugares, lo cual ocasionaba molestias. Así ocurrió en 1583, cuando el cabildo mandó decir al obrero mayor que hiciera el tablado que se acostumbraba poner para los prebendados el día de Corpus porque se subían en él "hombres y mujeres con poco comedimiento y no dan lugar a los dichos señores". ${ }^{64}$

Para la fiesta de Corpus del año 1589 al parecer hubo algunos cambios. El cabildo mandó que en lo sucesivo, al terminar la hora nona, se fuera a la víspera de Corpus en procesión al sagrario de los curas, con

60

(1)
libro 4 (1588-1605), sesión de cabildo de 31 de enero de 1589, ff. 13v-14. Y en 1601 se mandó que dicha capilla asistiera con el cabildo a donde quiera que éste fuera a procesiones, misas y funerales. ACCMM, actas de cabildo, libro 4 (1588-1605), sesión de iglesia no vayan fuera a cantar, so pena de ser puntados". ACCMM, actas de cabildo, cabildo del 12 de junio de 1601, f. 240v. ACCMM, actas de cabildo, libro 4 (1588-1605), sesión de cabildo del 28 de febrero de 1595, ff. 118v-119. En 1588 se había ordenado incluso que quienes sirvieran como ministriles acudieran a casa del maestro unos días antes de la fiesta de Corpus para aprender el canto y ser aprobados en él por dicho maestro, o serían penados. ACCMM, actas de cabildo, libro 4 (1588-1605), sesión de cabildo del 10 de junio de 1588, ff. 256v- $157 \mathrm{v}$. ACCMM, libro 2 (1559-1576), sesión de cabildo de 13 de mayo de 1575, f. 308.
64 ACCMM, libro 2 (1559-1576), sesión de cabildo de 14 de mayo de 1583, f. 171v.

63

ACCMM, actas de cabildo, libro 4 (1588-1605), sesión de cabildo del 4 de diciembre de 1590, ff. 35v-36v.

En 1589 se ordenó notificar a la capilla "que si quisieren de hoy en adelante ir a cantar fuera de esta santa iglesia a otra parte que habiendo de haber música en esta santa 
palio y hachas encendidas, y se llevara la custodia con el Santísimo Sacramento hasta en medio del altar mayor con mucha solemnidad. Para ello, se pidió que el presidente, ataviado con capa, portara la custodia con el Sacramento, y puesto éste en sus andas, empezaran las vísperas, y se rezaran los maitines a las cuatro y media, y una vez terminados se guardara el Santísimo Sacramento. ${ }^{65}$ A los capellanes de coro, por su parte, se les notificó que "no falten en todo este ochavario de Corpus Christi a todas las horas en esta santa iglesia, so pena de un peso a cada uno que faltare". ${ }^{66}$ En 1591 se volvieron a tomar medidas para realzar la dignidad de la fiesta. En cabildo, los prebendados señalaron que

por la edificación y buen ejemplo que se daba en el pueblo, particularmente por lo mucho que se edifican los indios, mandaron que en las procesiones del Santísimo Sacramento que se hacen dentro y fuera de la iglesia todos los capitulares tomen el incensario para incensar el Santo Sacramento que en la procesión se lleva, empezando desde el presidente y por su tanda sin quedar ninguno hasta el mayordomo, y si la procesión no se hubiere acabado, vuelva otra vez a tanda. ${ }^{67}$

En mayo de 1595, en medio de algunos conflictos con las órdenes religiosas por la precedencia en las ceremonias, se dio el primer decreto que prohibía que la capilla saliera a otras iglesias en la celebración de dicha la fiesta de Corpus y su octava:

teniendo atención y consideración a su oficio y obligación y que más en particular les obliga en la celebridad del día del Santísimo Sacramento con toda su octava cerrada, en la cual es necesario precisamente la asistencia de la capilla, ministriles y órgano, y porque el domingo infraoctavas han acudido de parte del convento de Santo Domingo de esta ciudad a pedir para el dicho día la dicha capilla y ministriles y de haberse dado ha [...] causado nota y escándalo en el pueblo cristiano juzgando al dicho cabildo por menos providente de desnudarse de los ministros que tan necesarios le son para aquel día por acudir a la contemplación del tercero, y para que esto cese y el servicio de Dios

\footnotetext{
65 ACCMM, actas de cabildo, libro 4 (1588-1605), sesión de cabildo del 30 mayo de 1589, ff. 18-18v.

66 ACCMM, actas de cabildo, libro 4 (1588-1605), sesión de cabildo del 26 de mayo de 1589, f. 18. ACCMM, actas de cabildo, libro 4 (1588-1605), sesión de cabildo del 3 de agosto de 1591, ff. $54 \mathrm{v}-55$.
} 
Nuestro Señor vaya adelante y la celebridad de la octava se celebre con la puntualidad, ornato, asistencia y devoción que se debe y conviene [...] declaraba por negada ahora y para siempre la dicha capilla y ministriles para que no puedan faltar ni falten de esta dicha santa iglesia a hora ninguna, sin embargo que por cualquier monasterio o monasterios se pida, porque en concurrencia semejante corre la obligación en conciencia haber de acudir primero a esta dicha catedral. ${ }^{68}$

Aquella prohibición estuvo a punto de extenderse a los conventos de monjas en 1601. En sesión capitular de junio, los prebendados se quejaron porque, si bien se exigía que se diera mayor solemnidad a la fiesta de Corpus y su octava, parecía contradictorio que dicho día se diera licencia a la capilla para que, dejando la catedral como "negocio accesorio, acudiesen a celebrarla a las monjas de Concepción", lo que generaba "murmuración" entre la población y a la fábrica se causaba daño. Mas en aquella ocasión se acordó que se mantendría la costumbre con dicho convento, por ser el más antiguo de la ciudad. Aquel acuerdo no dejó satisfecho al deán, Luis de Robles, quien dijo que apelaría dicha resolución. ${ }^{69}$

La fiesta de Corpus absorbía, pues, el mayor interés del cabildo, además de que Moya dio un fuerte impulso a la celebración. En 1584 el arzobispo propuso mandar hacer una custodia para el Santísimo Sacramento que se pretendía estuviera lista para la celebración del Tercer Concilio Provincial. ${ }^{70}$ Dicha pieza quedó a cargo del platero Pesquera y el cabildo acordó aportar dos mil pesos de los diezmos de Pánuco para ella. ${ }^{71}$ Dos años después también se puso en marcha el proyecto de hacer un monumento que serviría para poner dicha custodia en la fiesta del Santísimo Sacramento, cuando solía exhibirse a la puerta de la iglesia. ${ }^{72}$ Para 1595 ,

68 ACCMM, actas de cabildo, libro 4 (1588-1605), sesión de cabildo del 12 de mayo de 1595, ff. 120-120v. Servían entonces como cantores los presbíteros Francisco de Barrientos, Gabriel López y Juan Galiano y los seglares Francisco de Suazo, Tomás López, Juan de Salcedo, Nicolás Crespo, Alonso de Herrera. Como ministriles estaban Francisco de Covarrubias, Juan Maldonado, Lorenzo Martínez y Andrés de Molina.

69 f. $262 \mathrm{v}$.

70

71

72 f. $221 \mathrm{v}$ 
empero, aquel proyecto seguía sin poder realizarse debido a su costo. Dicho año, sin embargo, se acordó iniciarlo gracias a que el Ayuntamiento de la ciudad se ofrecía a cooperar con mil pesos; además, la Cofradía de la Caridad dijo sumar otros 500, y el virrey encargarse de la mano de obra y los materiales. ${ }^{73}$ A pesar de todo, en mayo de 1597 se seguía insistiendo en el cabildo en que no era justo que la catedral, por ser la metropolitana, "donde todas las demás iglesias tienen la mira", estuviera "tan desacomodada como hoy lo está de monumento". ${ }^{74} \mathrm{Y}$ así continuaron las cosas aún para finales de siglo. En 1598 se presentó el problema del costo nuevamente, pues se dijo que su valor alcanzaría los 14 mil pesos, mas los prebendados insistieron en que no pasara de 8 mil, ${ }^{75}$ y todavía en 1601 se mandaba apresurar a los oficiales que tenían a su cargo el monumento porque llevaban ya mucho tiempo sin terminarlo. ${ }^{76}$

\section{Los actores del ritual}

Uno de los puntos en los que se insistió entre 1570 y 1600 fue la mejor formación del clero y la reforma de sus costumbres. Desde el periodo de Montúfar éste fue un tema recurrente en su correspondencia con el Consejo de Indias. Se impusieron acotaciones a aquellos que deseaban recibir órdenes y a los que ya gozaban de ellas, con la finalidad de que fueran eclesiásticos adecuados que contaran con las características necesarias para el ministerio. El prelado insistió, además, en que los miembros de los cabildos eclesiásticos, empezando por el suyo, cumplieran estrictamente sus obligaciones cultuales. Su principal tarea era el rezo de las horas canónicas. En sus reglas de coro de 1570, Montúfar estipuló que, dado que tales ministros se alimentaban del patrimonio de Cristo, tenían la obligación de alabarlo en nombre de todo el pueblo cristiano, pues en ello radicaban el decoro y el honor de su oficio, "de modo que sobremanera

73

74

75

76 1601. Este año el cabildo aceptó una propuesta de Alonso Arias que decía que al "poco
respeto" con que se sacaba y metía el Santísimo Sacramento cuando se renovaba,
hacer gratis algún artefacto para dicho efecto. ACCMM, actas de cabildo, libro 4 (1588-
1605), sesión de cabildo de 14 de agosto de 1601, f. $266 \mathrm{v}$.

ACCMM, actas de cabildo, libro 4 (1588-1605), sesión de cabildo del 14 de abril de 1597, f. $117 \mathrm{v}$.

ACCMM, actas de cabildo, libro 4 (1588-1605), sesión de cabildo del 6 de mayo de 1597, f. 175.

ACCMM, actas de cabildo, libro 4 (1588-1605), sesión de cabildo del 21 de abril de 1598, f. 197.

ACCMM, actas de cabildo, libro 4 (1588-1605), sesión de cabildo del 27 de noviembre de 
nos gloriemos y vigilemos en rezar y cantar atentamente". ${ }^{77}$ Para ello se buscó que los provisores de los obispados examinaran a cualquier persona que pretendiera ordenarse. Debían vigilar que antes de dar su licencia para que un cura pudiera cantar misa estuviera "muy bien instructo en las ceremonias de la misa, según el ordinario de nuestra Iglesia mexicana, porque no se dé lugar a diversidad de ceremonias". ${ }^{78}$

Estas reformas fueron continuadas por Pedro Moya de Contreras para quien la solemnidad y boato del culto eran elementos que debían desarrollarse por ser necesarios en la liturgia. Durante este gobierno arzobispal se insistió en la necesidad de incluir en la catedral un maestro de ceremonias y un sochantre. Fue precisamente en el Tercer Concilio Provincial, presidido por este prelado, cuando por primera vez se ordenó que para contar con un mejor orden en el coro y en los oficios divinos se nombrara dicho maestro:

Establézcase en cada catedral por el obispo y cabildo un maestro de ceremonias, que sea sacerdote de buenas costumbres y muy ejercitado en los divinos oficios y ceremonias, dotándole por iguales partes el cabildo, obispo y fábrica. Será oficio del maestro de ceremonias advertir de sus deberes tanto a los que asisten al coro como a los que sirven en el altar, para que en uno y otro se observe el rito de las ceremonias. ${ }^{79}$

En lo que se refiere al cabildo, se advirtió que su principal obligación eran el culto y los oficios divinos: las horas canónicas en el coro, las misas capitulares y las procesiones. El que los capitulares asistieran diariamente a la celebración de las horas y oficios de la catedral dotaba de dignidad al culto. El Concilio de Trento había dispuesto la obligación que tenían de lo anterior todos aquellos que gozaran de una prebenda. El aumento de distribuciones para los prebendados que asistieran al coro, aunque incentivó su asistencia a las horas canónicas, no erradicó el descuido de su celebración; incluso en la Península, desde siglos atrás, era común el abandono del coro cuando ya habían ganado la distribución sin terminar el oficio, mantener conversaciones entre capitulares, rezar en privado mientras se hacía la celebración, pasear por la catedral sin hábito, etcétera. En la catedral de México, en 1583, se advirtió que los prebendados,

\footnotetext{
77 "Orden que debe observarse en el coro".

78 Primer Concilio Provincial Mexicano, 1555, estatuto XLV. Martínez, Concilios Provinciales Mexicanos.

79 Tercer Concilio Provincial Mexicano, libro III, tít. XV, cap. III, "Oficios del maestro de ceremonias". Martínez, Concilios Provinciales.
} 
con la finalidad de evadir su asistencia al rezo de las horas, "procuraban comisiones y oficios por faltar al coro, poniéndole presente en el cuadrante con achaque de las dichas comisiones y oficios". Por tal razón se ordenó "que de hoy en adelante no se le dé oficio ni comisión a ningún señor prebendado que lo pidiere, so pena de diez pesos de oro común al señor prebendado que votare a favor del tal oficio o comisión que pidiere". ${ }^{80}$

Como se dijo, otra de las obligaciones de los prebendados y por cuya falta eran reprendidos es su inasistencia a las ceremonias, sobre todo aquéllas en las que no ganaban estipendio alguno. En 1583 se ordenó que, debido a que varios se excusaban de salir a los oficios a los que había obligación de asistir, en adelante ninguno pudiera eludir su asistencia a las actividades donde no hubiera "interés ni obvención, y por los dichos señores deán y cabildo la mayor parte de ellos se determinare de verse hacer y salir a los dichos acompañamientos y cualquiera de ellos so pena de diez pesos de oro común a cada uno que lo contrario hiciere". Además, se ordenó que para que las faltas fueran justas, en el caso de enfermedad se presentara certificación de un médico, el cual a su vez sería señalado por el cabildo y a quien se le encargaría "conciencia en ello". También se advirtió que en caso de eludir la valoración médica y fingir legítima enfermedad, aparte de la pena, todo el tiempo que se tomara de patitur se le convertiría en puntos (faltas). ${ }^{81}$

Durante el periodo de Moya no sólo los prebendados fueron conminados a cumplir con su presencia en las diversas ceremonias y los rezos cotidianos, sino también los oficiales menores como los capellanes, acólitos, mozos de coro y sacristanes. Ejemplo de ello fue cuando, en 1586, el cabildo mandó notificar a los sacristanes mayor y menor, por "segundo apercibimiento", que se les impondría una pena de cuatro tomines por cada vez que faltaran al culto. Por ello se les recordó que su presencia era necesaria desde la hora de prima hasta las once, y si al mediodía no se hubieran acabado las horas, debían esperar hasta que terminaran; por la tarde, debían asistir hasta que se acabaran de decir los maitines. Asimismo se les ordenó no ausentarse de la iglesia a menos que fuera para atender asuntos de ésta o contar con licencia del presidente, que vistieran con sobrepellices y no subieran al altar mayor sin ellas. Además se les pidió que no consintieran "poner recaudo ni encender lumbre en el altar mayor a negros ni a indios ni en los demás altares si no fuere con

\footnotetext{
80 ACCMM, actas de cabildo, libro 3 (1576-1588), sesión de cabildo del 18 de junio de 1583, ff. 173v-174.

81 ACCMM, actas de cabildo, libro 3 (1576-1588), sesión de cabildo del 27 de septiembre de 1583, ff. 182v-183.
} 
alguna necesidad y consecutivamente enciendan las velas en empezando las horas y en acabadas las apaguen so pena de los cuatro tomines". ${ }^{82}$

Otro de los aspectos en que se insistía fue en la correcta apariencia y conducta de aquellos que servían en la catedral. Muestra de ello fue cuando, en 1573, llegó al cabildo catedralicio una petición de Pedro Díaz de Agüero, fiscal del arzobispado de México, en la que presentaba una queja contra los ministros de la catedral. Según denunció, había:

muchos cantores, sacristanes y otras personas que sirven en esta santa iglesia y en las demás de esta ciudad y arzobispado y no traen el hábito que conviene a los oficios que tienen y así mismo contra otras personas que sin ser de orden sacro traen manteo y sotana [...] y andan a caballo y hacen otros excesos profanando el hábito sacerdotal. ${ }^{83}$

El cabildo mandó notificar a los sirvientes de la catedral que "los que trajeren sotanas y manteos" anduvieran en la ciudad con la decencia que estaba mandada por el cabildo, o serían retirados de sus oficios. En la bula de erección se declaró que las dignidades, los beneficiados y acólitos tenían obligación de asistir al oficio divino. Los racioneros debían cantar las pasiones, los medios racioneros las lecciones de maitines, lamentaciones y profecías, y en los días de mucha solemnidad dignidades y canónigos debían cantar con los racioneros en el coro. Esto fue necesario sobre todo durante los primeros años de la catedral, debido a que no se dotaron todas las plazas instituidas; sin embargo, se preveía ampliar los beneficios hasta el número estipulado a medida que aumentaran las rentas de la catedral.

Para 1575, con miras a fortalecer el culto divino, se decidió que hubiera ocho capellanes de coro (y no seis como mandaba la Bula de Erección de 1534) con el salario de 100 pesos de minas anuales. Hasta entonces, los tres capellanes que servían en la catedral gozaban de la mitad de ese sueldo. Para contratar a cinco ministros más que sirvieran en ese oficio se mandaron poner edictos. ${ }^{84}$ Con esta nueva disposición se buscaba aumentar el número de ministros del culto y elegir a los mejor preparados. Los nuevos capellanes de coro contratados al año siguiente fueron Pedro

82

84 ff. $310-310 v$. f. $280 \mathrm{v}$.

ACCMM, actas de cabildo, libro 3 (1576-1588), sesión de cabildo del 7 de noviembre de 1586, ff. 237-238v. ACCMM, actas de cabildo, libro 2 (1559-1576), sesión de cabildo del 28 de julio de 1573, ACCMM, actas de cabildo, libro 2 (1559-1576), sesión de cabildo del 28 de junio de 1575, 
López y Antonio Ortiz, cuyas obligaciones serían cantar en el facistol. ${ }^{85}$ Entre las tareas de estos capellanes estaban el servicio del coro y el rezo de las horas canónicas. Se advirtió, sin embargo, que debían cesar sus frecuentes faltas ocasionadas "por ir a los entierros por su particular interés", recordándoles que por ello se les había aumentado el salario a 100 pesos. ${ }^{86}$

Se acordó también la contratación de cuatro acólitos, cuyo oficio sería acudir de ordinario a las horas diurnas, excepto a prima, para que diesen y pusiesen las capas en el coro. Servirían por semana de manera alternada dos de ellos el altar y los otros dos el coro. Entre sus tareas estaba asistir al preste y sus ministros cuando salieran a la sacristía para revestirse, tendrían a su cargo los libros, mantendrían el coro "limpio y bien aderezado" e incluso tendrían la tarea de "quitar la gente de las puertas" ${ }^{87}$ Por estas tareas se les señaló un salario de 50 pesos de minas. Entre los acólitos contratados figuraron Gonzalo de Villalobos, Gerónimo de León ${ }^{88}$ y Juan Méndez, éste también con el cargo de corista. ${ }^{89}$ En 1576 se contrató, además, una persona para que ejerciera el oficio de apuntador del coro y se encargara del cuidado de los libros: Pedro de Paraga, clérigo, presbítero y capellán de coro realizaría ese trabajo.

La correcta celebración del ritual dependía de quien presidiera el coro (el deán era el presidente de dicho recinto y, en su ausencia, lo era el arcediano), el presidente ocupaba un sitio determinado. En 1586, para conservar la decencia dentro del recinto, se mandó que se guardara y cumpliera lo de la tabla que estaba en el cabildo, en la cual se trataba "del orden que en coro se ha de tener". ${ }^{90} \mathrm{~A}$ pesar de estos empeños, no fueron raras las rencillas e incluso los insultos o golpes dentro del coro. En 1581, en sesión capitular, se trató sobre un conflicto que tuvo lugar entre algunos capitulares. Según se comentó, el miércoles 29 de marzo

85

86

89

90

ACCMM, actas de cabildo, libro 2 (1559-1576), sesión de cabildo del 31 de marzo de 1576 , ff. 326v-327.

ACCMM, actas de cabildo, libro 3 (1576-1588), sesión de cabildo del 14 de diciembre de 1576, f. 20.

ACCMM, actas de cabildo, libro 2 (1559-1576), sesión de cabildo del 19 de agosto de 1575 , f. 312v.

ACCMM, actas de cabildo, libro 2 (1559-1576), sesión de cabildo del 26 de agosto de 1575, ff. 312v-313.

ACCMM, actas de cabildo, libro 2 (1559-1576), sesión de cabildo del 9 de septiembre de 1575 , f. $314 \mathrm{v}$.

ACCMM, actas de cabildo, libro 3 (1576-1588), sesión de cabildo del 11 de julio de 1586, f. 232 . 
hubo palabras de desacato entre el doctor don Juan Zurnero, arcediano que presidía, el canónigo Cárdenas y el racionero Cueva. Deán y cabildo en su mayoría dijeron que en el conflicto el canónigo y racionero no quisieron

bajar de las sillas altas a cantar al facistol, por no haber quién cantase bajando como bajó el dicho señor arcediano siendo presidente y estando todos obligados a cantar cuando el presidente baja, conforme a la regla del coro, y las porfías y alboroto que sobre esto hubo, estando en las horas y después la pesadumbre que pasó en ello el dicho coro con grande nota entre dicho señor arcediano y el señor racionero Cueva no guardando el decoro del cabildo y de sus mismas personas y atento a lo dicho y no haber guardado los estatutos y reglas del coro y cabildo confirmadas por Su Señoría Ilustrísima el señor Arzobispo, por donde se manda que al presidente se tenga todo respeto. ${ }^{91}$

En consecuencia, se multó a esos prebendados y se les prohibió la entrada a las reuniones capitulares, en particular al canónigo Cárdenas "por haber sido inobediente y porfiado al presidente". Dicho capitular quedaría excluido por dos meses de tal privilegio. No obstante, días después se menciona que Cárdenas entró y se sentó, a pesar de que se le envió a decir que para entrar diese petición de lo que pretendía; el canónigo Cabello afirmó habérselo dicho, pero que había sido menospreciado por el prebendado, quien se salió de aquella sesión profiriendo palabras en contra del "orden y decencia" debidos. Por lo tanto, días después se propuso el orden que convendría tener en el subir y bajar de las sillas del coro de la iglesia a fin de que no sucediese cosa semejante. La mayor parte votó porque todos estuvieran en las sillas altas y no bajaran a las del coro si no fuere por mandato del presidente, y en dado caso que no bajaran al facistol a las vísperas y a la misa, perderían la hora y se les apuntaría. ${ }^{92}$

Todas las medidas adoptadas buscaban dar mayor categoría y realce al ritual catedralicio. El reforzamiento de la imagen del cabildo eclesiástico empezaba por su catedral y se debía proyectar hacia el exterior de ella. Así, al tiempo de las reparaciones hechas al edificio catedralicio, en la década de 1580 se fabricó una nueva sillería del coro y se buscó tener

91

92 西 f. $114 \mathrm{v}$. 
un orden adecuado en los libros, los ornamentos y la disciplina de los capitulares y oficiales de la catedral. Lo que estaba en juego era la preeminencia misma del cabildo eclesiástico y de su catedral.

\section{Conclusión}

Es poco lo que sabemos aún acerca de la construcción del ritual catedralicio en la Nueva España. Durante el siglo Xvi se fundaron las catedrales de Tlaxcala, México, Valladolid, Guadalajara, Antequera, Chiapas y Mérida. Saber más acerca de sus orígenes y sus cabildos eclesiásticos permitirá conocer al clero que se conformó en esas corporaciones y la manera en que configuraron sus iglesias en el ámbito local. Si bien es un lugar común en la historiografía afirmar que las catedrales se fundaron como sufragáneas de la de Sevilla, en la práctica esta afirmación es poco útil cuando queremos entender cómo era la vida eclesiástica en las diversas diócesis de la Nueva España. En un interesante artículo, Leticia Pérez Puente ha señalado que aún durante el siglo XVII la composición de los cabildos eclesiásticos americanos muestra que estaban lejos de parecerse a sus pares peninsulares. ${ }^{93}$ Ante grandes diferencias, creemos fundamentales los análisis de caso para conocer mejor la forma en que se estructuraron estas catedrales en tierras americanas y cómo organizaron su espacio social y religioso.

En este caso nos hemos centrado en la catedral de México del último tercio del siglo XVI. Durante ese tiempo la catedral dio pasos seguros en su asentamiento. En el periodo comprendido entre 1534, fecha en que se expidieron los estatutos para su erección, y 1554, cuando llegó su segundo arzobispo, la catedral sentó las bases de su organización capitular, económica y ritual. Ya convertida en sede arzobispal, la catedral de México se consolidó gracias a un cabildo que impulsó la construcción de un ritual digno de la principal iglesia del reino. Con esto en mente, se reforzó el espíritu de cuerpo y a la par se buscó distinguir al cabildo catedral de las demás corporaciones de la ciudad. Las ceremonias y procesiones públicas eran las ocasiones para que los prebendados lucieran la magnificencia de su oficio. Para ello también fortalecieron el ritual catedralicio mediante la contratación de maestros de capilla, mozos de coro, cantores, ministriles, capellanes, acólitos, sochantres, sacristanes y demás personal que ayudara a la celebración del culto. Para el último tercio del siglo, las buenas relaciones con su arzobispo Moya de Contreras y el crecimiento de las rentas decimales dieron al cuerpo capitular la estabilidad necesaria para el fortalecimiento de su sede. Para la década de 1590 el cabildo logró cubrir sus 27 plazas

93 | Pérez Puente, "Los cabildos". 
y de él dependían, además, unos 40 oficiales que ayudaban al servicio del coro y del culto catedralicio en general. La compra de los ornamentos y libros necesarios fue otro aspecto que no se pasó por alto. Esperamos que este trabajo permita dar luces de la importancia del ritual catedralicio para comprender la historia de nuestras iglesias matrices novohispanas.

\section{$\operatorname{Anexos}^{94}$}

\begin{tabular}{|llcc|}
\multirow{2}{*}{\multicolumn{1}{c}{ Sochantres (1570-1600) }} & \multicolumn{3}{c|}{} \\
\cline { 2 - 4 } Nombre & \multicolumn{1}{c|}{ Salario } & Ingreso & Egreso \\
\hline Pedro Garcés & & 1557 & 1575 \\
Marcos Tello & 400 pesos & 1577 & 1582 \\
Juan de Cañas & 300 pesos de oro común & 1584 & 1585 \\
Antonio Ortiz & 300 de oro común & 1585 & 1589 \\
Bartolomé Franco & & 1589 & 1603 \\
\hline
\end{tabular}

\begin{tabular}{|lcccc|}
\multicolumn{2}{|c}{ Maestros de capilla $(1570-1600)$} & & & \\
\cline { 3 - 5 } Nombre & Órdenes & Salario & Ingreso & Egreso \\
\hline Juan de Victoria & & & 1573 & 1575 \\
Hernando Franco & Clérigo, Presbítero & 450 pesos de oro común & 1575 & 1585 \\
Juan Hernández & Clérigo, Presbítero & 450 pesos de oro común & 1586 & 1621 \\
\hline
\end{tabular}

\begin{tabular}{|llcc|}
\cline { 2 - 4 } \multicolumn{1}{c}{ Organistas $(1570-1600)$} & \multicolumn{3}{c|}{} \\
\cline { 2 - 4 } Nombre & \multicolumn{1}{c|}{ Salario } & Ingreso & Egreso \\
\hline Manuel Rodríguez & 200 pesos de minas & 1566 & 1595 \\
Pedro de Vargas & 80 pesos de minas & 1566 & 1567 \\
Alonso Rodríguez de Mesa & 350 pesos de oro común & 1595 & 1619 \\
\hline
\end{tabular}

\begin{tabular}{|llcc|}
\multicolumn{1}{|c}{ Mozos de coro (1570-1600) } & & \\
\cline { 2 - 3 } Nombre & Salario & Ingreso & Egreso \\
\hline $\begin{array}{l}\text { Miguel Calvo } \\
\text { N. Uzeda }\end{array}$ & 8 pesos de minas & 1576 \\
Martín Díaz & & 1576 & \\
Luis & & 1578
\end{tabular}

\footnotetext{
$94 \begin{aligned} & \text { La información utilizada en los cuadros que presentamos como anexos ha sido tomada } \\ & \text { del ACCMM. }\end{aligned}$
} 


\begin{tabular}{|llcc|} 
Nombre & Salario & Ingreso & Egreso \\
\hline Gaspar & & 1579 & \\
Diego de Villalobos & 12 pesos de minas & 1586 & \\
Florián de Mena & 12 pesos de minas & 1586 & \\
Alonso García & & 1587 & \\
Jerónimo Arias & & 1588 & \\
Juan Arias & 8 pesos & 1588 & 1591 \\
Esteban de Zamora & & & 1589 \\
Medina & 8 pesos & 1589 & \\
Roque Crespo & 8 pesos & 1589 & 1592 \\
Nicolás Crespo & 16 pesos de minas & 1590 \\
Bartolomé Valadés & & 1590 \\
Pedro de Acosta & & 1593 & 1601 \\
Juan de Silva & 16 pesos de minas & 1595 & 1596 \\
Hernando de Covarrubias & & 1595 & \\
Sebastianico & & 1599 & 1599 \\
Alonsico de Herrera & & & 1600 \\
\hline Juan Martínez & 16 pesos de minas & & \\
Diego Maldonado & & & \\
Martín de Cuellar & & 1590 & \\
\hline
\end{tabular}

\begin{tabular}{|lllcc|}
\multicolumn{1}{c}{ Cantores (1570-1600) } & \multicolumn{3}{c|}{} \\
\cline { 2 - 5 } Nombre & Tesitura & \multicolumn{1}{c|}{ Salario } & Ingreso & Egreso \\
\hline Baltasar Torres & tiple & 16 pesos de minas & 1565 & 1579 \\
Juan Hernández & tiple & 200 pesos de oro común & 1568 & 1585 \\
Luis de Toro & & 50 pesos de oro común & 1572 & $1602 ?$ \\
Pedro Martín & & 100 pesos de oro común & 1572 & 1584 \\
Agustín Díaz & & 120 pesos de salario & 1574 & 1596 \\
Serván Ribero & tiple & 120 pesos de oro común & 1574 & 1616 \\
Bartolomé de Luna & & 200 de oro común & 1574 & \\
Lorenzo de Sola & tenor & 50 de oro común & 1575 & 1597 \\
Baltazar de Torres & & 50 pesos de minas & 1575 & \\
Fabián Gutiérrez & & 20 de minas & 1575 & 1610 \\
Cristóbal de Torres & & 16 de minas & 1575 & \\
(Álvaro/Alonso) Trujillo & & 200 de oro común & 1575 & \\
Andrés Pérez & tiple & 20 de oro común & 1576 & \\
Francisco Mirón & tiple & 20 de oro común & 1576 & 1578 \\
Antonio Ortiz de Zúñiga & & 100 pesos de oro común & 1577 & 1626 \\
Cristóbal de Zevallos & & 150 de tepuzque & 1577 & \\
Martín Díaz & & 200 pesos de minas & 1578 & \\
\hline
\end{tabular}




\begin{tabular}{|c|c|c|c|c|}
\hline Nombre & Tesitura & Salario & Ingreso & Egreso \\
\hline Baltasar de Torres & & & & 1579 \\
\hline Domingo Pérez & & & 1579 & \\
\hline $\begin{array}{l}\text { Domingo Pérez de } \\
\text { Castro }\end{array}$ & & 200 pesos de tepuzque & 1579 & 1592 \\
\hline Francisco de Barrientos & & 200 de tepuzque & 1581 & 1599 \\
\hline Pedro López & & 100 pesos de tepuzque & 1581 & 1582 \\
\hline Alonso de Trujillo & & 200 pesos de oro común & & 1582 \\
\hline Marcos Tello & contrabajo & 200 pesos de oro común & & 1582 \\
\hline Juan de Cañas & & 50 pesos de minas & 1583 & \\
\hline Martín de Arreola & & 50 pesos de oro común & 1584 & \\
\hline Luis Coronado & & 20 de minas & 1584 & 1623 \\
\hline Gabriel López & & 200 pesos de oro común & 1586 & 1605 \\
\hline Gaspar Alfaro Díaz & & 100 pesos de oro común & 1586 & 1589 \\
\hline Juan Galiano & tenor & 200 pesos & 1586 & 1616 \\
\hline Pedro del Carpio & & 60 pesos de tepuzque & 1586 & \\
\hline Alonso García & & 25 pesos de minas & 1587 & \\
\hline Andrés López & & 100 pesos de tepuzque & 1588 & \\
\hline Luis Montes de Oca & & 100 pesos de minas & 1588 & 1589 \\
\hline Gonzalo López & tiple & 300 pesos de oro común & 1589 & \\
\hline Miguel de Solís & & 250 pesos de tepuzque & 1589 & \\
\hline Bartolomé Valadés & & 8 pesos de minas & 1590 & \\
\hline Pedro de Acosta & & 8 pesos de minas & 1590 & \\
\hline Tomás López & tiple & 120 pesos de oro común & 1590 & 1626 \\
\hline Pedro de Salcedo & tiple & 120 pesos de oro común & 1590 & 1600 \\
\hline Antonio de Yllana & & 50 de oro común & 1591 & 1601 \\
\hline Nicolás Crespo & & 200 pesos & 1592 & 1633 \\
\hline Francisco de Suazo & contralto & 100 pesos de tepuzque & 1594 & 1602 \\
\hline Alonso de Herrera & & 50 pesos de tepuzque & 1595 & 1596 \\
\hline Luis Barreto & tiple & 300 pesos de oro común & 1595 & 1636 \\
\hline Lorenzo Rubio & contralto & 100 pesos de tepuzque & 1596 & 1609 \\
\hline Antonio de Vera & contrabajo & 130 pesos de tepuzque & 1596 & 1619 \\
\hline Fabián Gutiérrez & contralto & 150 pesos de tepuzque & 1596 & 1599 \\
\hline Alonso de Santiago & contrabajo & 200 pesos & 1598 & 1599 \\
\hline Juan Martínez & & 16 pesos de minas & 1599 & \\
\hline Agustín de Navas & tenor & 200 pesos de tepuzque & 1600 & 1613 \\
\hline
\end{tabular}




\begin{tabular}{|c|c|c|c|c|}
\hline Nombre & Instrumento & Salario & Ingreso & Egreso \\
\hline Bartolomé de Luna & chirimía & 200 de oro común & 1574 & \\
\hline Francisco de Covarrubias & bajón & $\begin{array}{l}300 \text { pesos de oro } \\
\text { común }\end{array}$ & 1575 & 1601 \\
\hline Miguel de los Reyes & & $\begin{array}{l}250 \text { pesos de oro } \\
\text { común }\end{array}$ & 1575 & 1582 \\
\hline Rodrigo de Saavedra & & $\begin{array}{l}250 \text { pesos de oro } \\
\text { común }\end{array}$ & 1575 & 1598 \\
\hline Pedro de Ribas & sacabuche & $\begin{array}{l}250 \text { pesos de oro } \\
\text { común }\end{array}$ & 1575 & 1598 \\
\hline Bernardino Rodríguez & & $\begin{array}{l}250 \text { pesos de } \\
\text { tepuzque }\end{array}$ & 1581 & 1600 \\
\hline Julián Hurtado de Mendoza & & $\begin{array}{l}200 \text { pesos de oro } \\
\text { común }\end{array}$ & 1582 & 1582 \\
\hline Álvaro de Covarrubias & bajón & 200 ducados & 1582 & 1601 \\
\hline Juan Sánchez Maldonado & & 200 ducados & 1590 & 1595 \\
\hline Juan Maldonado & corneta & 250 ducados & 1590 & 1616 \\
\hline Lorenzo Martínez & bajón & 300 pesos & 1590 & 1611 \\
\hline Andrés de Molina & & 250 ducados & 1590 & 1601 \\
\hline Mateo de Arellano & & 250 ducados & 1590 & 1601 \\
\hline Juan Bautista & & & 1591 & \\
\hline Hijo 1 de Juan Bautista & & & 1591 & \\
\hline Hijo 2 de Juan Bautista & & & 1591 & \\
\hline Juan Bautista & sacabuche & 100 pesos & 1592 & 1601 \\
\hline Gaspar Maldonado & & 200 ducados & 1595 & 1601 \\
\hline
\end{tabular}

\section{Siglas}

ACCMM Archivo del Cabildo Catedral Metropolitano de México

AGI Archivo General de Indias

\section{Bibliografía}

Aviña Levy, Edmundo (editor)

Descripción del Arzobispado de México hecha en 1570, presentación de Luis García Pimentel, edición facsimilar de la de 1897, Guadalajara, s.p.i., 1976.

Barrio Gonzalo, Maximiliano

El clero en la España moderna, Madrid, Imprenta San Pablo, 2010. 
Becerra Jiménez, Celina

"Enseñanza y ejercicio de la música en la construcción del ritual sonoro en la catedral de Guadalajara", en Arturo Camacho Becerra (coord.), Enseñanza y ejercicio de la música en México, Guadalajara, Centro de Investigaciones y Estudios Superiores en Antropología Social, El Colegio de Jalisco, Universidad de Guadalajara, 2013, pp. 21-69.

Carreño, Alberto María

Un desconocido cedulario del siglo XVI perteneciente a la catedral metropolitana de México, México, Ediciones Victoria, 1944.

Castillo Flores, José Gabino

"Los primeros tropiezos en la conformación del ritual catedralicio: México, 1534-1570, en prensa.

Castillo Flores, José Gabino

"La catedral de México y su cabildo eclesiástico: 1530-1612", tesis de doctorado en historia, Zamora, El Colegio de Michoacán, 2013.

Cervantes de Salazar, Francisco

México en 1554. Tres diálogos latinos traducidos por Joaquín García Icazbalceta, notas preliminares de Julio Jiménez Rueda, México, Universidad Nacional Autónoma de México, 1939.

Civale, Gian Claudio

"Conflictos de poder entre la Inquisición y el cabildo de la catedral de Sevilla a mediados del siglo XVI", en Actas del Congreso Internacional Espacios de poder: cortes, ciudades y villas (siglos XVI-XVIII), vol. 2, núm. 5, Madrid, Universidad Autónoma de Madrid, 2002, pp. 269-324.

Díaz Cayeros, Patricia

"Ornamentación y ceremonia: la activación de las formas en el coro de la catedral de Puebla", México, Universidad Nacional Autónoma de México, Facultad de Filosofía y Letras, tesis de doctorado, 2004.

García Acosta, Virginia, Juan Manuel Pérez Zevallos y América Molina del Villar

Desastres agrícolas en México. Catálogo histórico, tomo I: épocas prehispánica y colonial (958-1822), México, Fondo de Cultura Económica, Centro de Investigaciones y Estudios Superiores en Antropología Social, 2003, pp. 96-97.

Gelineau, Joseph

Voices \& Instruments in Christian Worship, traducción al inglés de Clifford Howell, Collegeville, The Liturgicall Press, 1962.

Ladero Quesada, Miguel Ángel

"La Sevilla medieval", en Paín Dimas Borrego (coord.), Historia de Sevilla, Sevilla, Publicaciones de la Universidad de Sevilla, 1992, pp. 161-226. 
Lundberg, Magnus

Unificación y conflicto. La gestión episcopal de Alonso de Montúfar, OP, Arzobispo de México, 1554-1572, traducción de Alberto Carrillo Cázares, Zamora, El Colegio de Michoacán, 2009.

Martínez López-Cano, Pilar (coord.)

Concilios Provinciales Mexicanos. Época colonial, México, Universidad Nacional Autónoma de México, edición en CD, 2004.

Mazín Gómez, Óscar

El Cabildo catedral de Valladolid de Michoacán, Zamora, El Colegio de Michoacán, 1996.

Navascués Palacio, Pedro

"Los coros catedralicios españoles", en Actas del congreso internacional sobre el coro del maestro Mateo, Fundación Barrié de la Maza, 2001, pp. 23-41.

Peña Espinosa, Jesús Joel

"El oficio divino en la catedral de Puebla como representación de la identidad de su cabildo (1539-1597)", Dimensión antropológica, año XIX, vol. 55, mayo-agosto 2012, pp. 39-69.

Pérez Puente, Leticia

"Los cabildos de las catedrales indianas, siglos XVI y XVII", en Luis René Guerrero Galván (coord.), Las instituciones políticas indianas, México, Universidad Nacional Autónoma de México-Instituto de Investigaciones Jurídicas (en prensa).

Schwaller, John Frederick

Orígenes de la riqueza de la Iglesia en México. Ingresos eclesiásticos y finanzas de la Iglesia 1523-1600, México, Fondo de Cultura Económica, 1990.

Serrano, Luis

La traza original con que fue construida la catedral de México por mandato de su Majestad Felipe II, México, Universidad Nacional Autónoma de México, Escuela Nacional de Arquitectura, 1964.

Recibido: 24/11/2014. Aceptado: 22/05/2015

Letras Históricas / Número 14 / Primavera-verano 2016 / México / pp. 17-49 / ISSN: 2007-1140 